\title{
"Wholeness, Harmony, Radiance" and Women's Writing
}

\author{
LORRAINE WEIR
}

For if she begins to tell the truth, the figure in the looking-glass shrinks; his fitness for life is diminished.

Virginia Woolf, $A$ Room of One's Own

In The COURSe of a Discussion of aesthetics in $A$ Portrait of the Artist as a Young Man, Joyce's hero, Stephen Dedalus, expounds three Thomist principles which he takes to be essential to the work of art. "Three things are needed for beauty," he says, quoting Aquinas, "wholeness, harmony and radiance." 1 Although few would argue that mainstream criticism is still primarily Thomist in attitude and intent, it is clear that a majority of Canadian critics at least are still haunted by expectations of accessibility, verbal and structural simplicity, "life-likeness," and that contented sense of roundness, repletion which some expect to follow a good meal or a good novel. And it is not only fiction which is still subjected to these quaint criteria but poetry as well, despite the fact that many of our most respectable critics cling to antique notions of generic specificity. 
Poets are congratulated on the clarity, simplicity and appropriateness of their imagery, the measure of all three criteria being finally the critic's capacity to recognize his own world, his own perceptions and attitudes, translated for him by the poet. For Narcissus only one image will do.

It is, however, unlikely that he will drown, for in a patriarchal society his image is writ large and its power to exact conformity evident especially to all those whose images are other. Feminist critics have long held that women's writing presents radically different views of the world and that our capacity as readers to deal with these diverse and often "experimental" texts (texts, that is, which don't conform to mainstream expectations but have-some of them, at least-survived anyway) is limited by our training in traditional assumptions about literature. Let me take this argument one step further by asserting that in Canada the Realist tradition ${ }^{2}$ - grounded in Anglo-Protestant injunctions against ritual, "mystification" in language and doctrine and so on-has assumed the status of smug credo because its simpler manifestations so neatly reflect the image which Narcissus takes to be the "norm." One need not be a Marxist to see further that the norm in capitalist patriarchy is a bourgeois version of wholeness and harmony (though radiance might be seen as rather extreme). Critics as diverse as Georg Lukács, Ian Watt and Terry Eagleton have enabled us to see the ways in which the rise of the Realist mode in literature and of the middle class through the Victorian period not only coincided but reflected each other's ascendancy. To put a complex argument very briefly, then, we have in Canada a class of mainstream critics whose ideology is capitalist, bourgeois, patriarchal and, in its origins if not in current practice, Anglo-Protestant.

Narcissus values simplicity and accessibility in part because his life has been made simple through the labour of countless women whose correspondingly complicated lives are incomprehensible to him. His writing is accessible because it reflects the values of the power élite. The hallmark of the patriarchal voice at its best, this ideal of clarity is a false one which drowns in its own submissiveness to reigning power, avoids the struggle toward free speech, and moulds (in both senses) public understanding of texts by excluding from view that 
which does not give back the required reflection or - as in the case of Margaret Laurence-by assimilating into the bourgeois Realist tradition works which on the surface conform to its dictates. Thus we have the absurd irony of Laurence's novels being elevated in the canon above Alice Munro's "fragmented" fictions despite the fact that the wholeness of the former counterpoints the jaggedness, incompleteness and stubborn struggle against self-mutilation of the lives of many of the characters depicted. However easy Munro's "fragments" are on the surface to oppose to Laurence's continuum, the logical opposition in itself serves only to obscure the fact that Munro's style in its repetitions, is doubling back and restatement and "incompleteness" moves in itself away from the ideology which still possesses some of her characters. Where we have been taught to see more and less perfect accommodations to the tradition by these two writers, we may come to see a radically different phenomenon: a struggle to move theme and style toward open forms, forms which threaten Narcissus. Style itself is mimetic. Open texts challenge closed systems.

In struggling toward freedom we begin the journey out of exile, our language mirroring the knowledge which generations of women have shored against a system which excludes us, a system whose principles of wholeness and harmony have had as little to do at any time with the lives of women as of those of the members of any servant class. We move through a world which, as Louky Bersianik has said, proclaims its universality, its generality, its mass-produced truth; and we move through the dismembered bodies of our ancestors and ourselves.

Some would argue, like Adrienne Rich, that we need "re-vision"3 or, as Ann Saddlemyer recently said, that we must repossess critical terminology, remaking it to suit the manifold needs of women's texts, to deal with the "unspoken but always present subtext" and with the use of "symbol" where critics have been trained to expect 
"statement." If, as Saddlemyer maintained, it is the playwright's responsibility to make the work accessible to the audience, since theatre is by its very nature a "whole and healing art," then critics must devise ways of understanding which open the text out rather than struggling against it or obscuring it for others, practices not unknown among mainstream critics.

But I wonder about the criterion of accessibility and, although I respect the views of Rich and Saddlemyer and agree that in some circumstances our work as critics must be re-visionist, I wonder about all the hermetic texts in women's literature and about what we do when we open them out, making an often bitterly private tradition into a public one-public on Narcissus's terms. Telling the truth "slant,"4 as Emily Dickinson put it, has so deeply and persistently characterized our tradition that I wonder about using the language of Narcissus at all to straighten the slant or to undo what Adrienne Rich has called the "lies"5 which have been so much a part of women's lives and texts. Slant writing can never be made "whole"; to attempt to do so is to participate in our own de/composition.

I am not, however, suggesting that we amputate ourselves from the heritage of women's texts which feminist critics have only begun to study. Rather, it seems to me that we need to critique the very concept of wholeness which in all its forms has held us captive, often unknowingly complicit. For as long as we see the "half-saying," the concealed or unspoken subtexts, the use of symbol and rhetoric of camouflage as incomplete, partial, an imperfect "half-life," we are still participating in the doctrine of naive accessibility and in the judgements of Narcissus. Our task is a complex one, requiring us to be familiar with the intricate strategies of contemporary literary theory, for in this struggle theorists like Jacques Derrida and Michel Foucault who seek to deconstruct the phallogocentrism - the patriarchal control of structures of language and definitions of meaningof the Western humanist tradition are our allies. Those who would dismiss theory because of its difficulty or inaccessibility fall victim to the same arguments which have been used against women's writing. Feminist theory must, it seems to me, abjure the primitivist lethargy of those who refuse to see that the deconstruction of the Western humanist tradition is central to the work of naming the place where we find ourselves. 
In setting aside the illusions of closure, completion, stasis, perfection - the ideals of a patriarchal society which, as Simone de Beauvoir has reminded us, has never had to cope with the Sisyphean labours of housework', of the sheer dailiness of Woolf's "moments of being"7 - we enter the possibility of the open text, the so-called "fragment," the writing which exists not to valorize its author/ity ${ }^{8}$ but to be activated in the process of reading/making/collaborating. And if Narcissus, entering the water of his dream, finally drowns in accessibility, we may find ourselves in a familiar medium, knowing the underside of reflection to which we were consigned long ago. For the inaccessible, the complex and often contradictory, the jagged and incomplete, the discordant and dark are only Narcissus's terms for the writing which we have been doing all along. The image from below is our own. We can say that we have been drowned; we can say that we know how to swim. I prefer the latter.

Notes

This paper is a revised version of my contribution to the "Criticizing Mainstream Criticism" panel (speakers: Ann Saddlemyer, Louky Bersianik, France Théoret, Carolyn Hlus, and myself; moderator, Jennifer Waelti-Walters) at the Women and Words Conference, Vancouver, July I, I983. One of my functions as the final speaker was to draw together some of the points made by the other participants. I am grateful to the panelists for their insights from which I profited, especially to Ann Saddlemyer whose beautifully articulate statement helped me to formulate my own response more precisely, and to France Théoret for much conversation afterward.

${ }^{1}$ James Joyce, $A$ Portrait of the Artist as a Young Man, ed. Chester G. Anderson and Richard Ellmann (London, 1968), p. 216. Joyce's italics.

${ }^{2}$ Although the term Realism is usually assumed to be applicable solely or primarily to prose fiction, I am extending it here to include 
poetry and drama as well, and making that extension by way of the ideological assumptions inherent in the mode itself and in the writings of those mainstream critics who impose expectations grounded in this mode upon poetry and drama as well as prose fiction. Realism incorporates an attitude toward life, a set of expectations of texts and of situations which arise from its mimesis of the "norms" of bourgeois patriarchy.

${ }^{3}$ Adrienne Rich, "When We Dead Awaken: Writing as ReVision," On Lies, Secrets, and Silence (N.Y., 1979), pp. 33-49.

${ }^{4}$ Emily Dickinson, The Complete Poems, ed. Thomas H. Johnson (Boston, 1960), p. 506, no. I129.

${ }^{5}$ Rich, "Women and Honor: Some Notes on Lying," op. cit., pp. I86-94.

${ }^{6}$ Simone de Beauvoir, The Second Sex, trans. H.M. Parshley (N.Y., I96I), p. 425.

7Virginia Woolf, Moments of Being, ed. Jeanne Schulkind (N.Y., 1976).

${ }^{8}$ See Michel Foucault's essential essay, "What Is An Author?", in Language, Counter-Memory, Practice, ed. Donald F. Bouchard, trans. D. F. Bouchard and Sherry Simon (Ithaca, 1977), pp. II4-38.

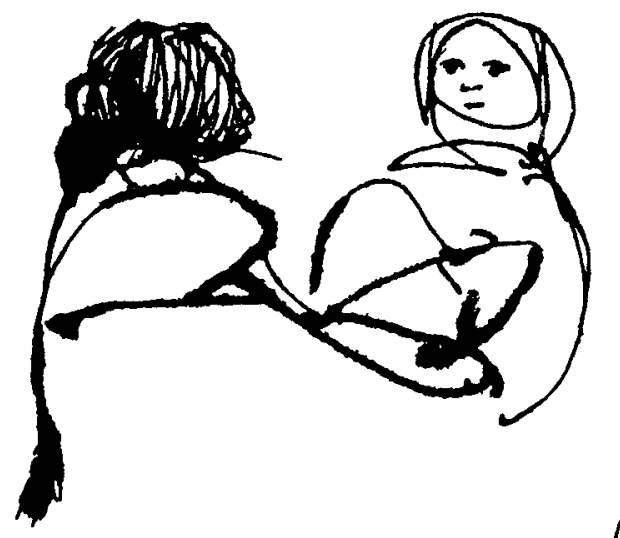

\section{Clive'g}

